\title{
The Pinhole Technique in the Treatment of Gingival Recession Defects
}

\author{
Mostafa Diana $^{1 *}$, Al Shateb Safa ${ }^{2}$, Thobaiti Bashayer ${ }^{2}$, Alotaibi Bariah $^{2}$, Al Rabeea Sukania ${ }^{2}$, and Aldossry \\ Sarah $^{2}$
}

${ }^{1}$ Clinical Periodontics, Preventive Dental Sciences Department, AlFarabi Colleges, Riyadh, KSA

${ }^{2}$ AlFarabi Colleges, Riyadh, KSA

Submission: July 22, 2020; Published: August 17, 2020

*Corresponding author: Diana Mostafa, Preventive Dental Sciences, Al-Farabi Colleges, KSA

Abstract

Introduction: Numerous surgical techniques have been advocated to treat the gingival recession (GR) either single or multiple defects including free gingival autograft, subepithelial connective tissue graft, lateral repositioned flap, double papilla flap, coronally repositioned flap , and guided tissue regeneration techniques. Despite these considerable number of studies, the surgical difficulties, time, and patients' discomfort are still the main obstacles. Also, the morbidity associated with the secondary graft sites has generated the interest and need of other modalities to achieve the esthetic and functional requirements without any complications.

Aim: Our purpose was to highlight the achievability of novel pinhole surgical technique (PST) in the treatment of GR as it is one of the recent minimally invasive modalities of RC with minimal complications.

Methodology: The study protocol was based on the review of the English human studies publications which were published from 2010 to July 2020 using the PST in the treatment of GR. We used databases from scientific websites such as PubMed, Scopus, and Google scholar.

Results and Conclusion: Only five studies were considered appropriate for our review. The main outcome of comparing the included clinical studies was that the PST achieves non-invasive treatment of an unlimited number of GR defects with high predictable esthetic results in less time in one appointment without donor sites or exposure of the graft, which make PST a promising modality that reaches the periodontist ambition.

Keywords: Pinhole surgical technique; Gingival recession treatment; Root coverage

Abbreviations: ADM: Acellular dermal matrix; CAL: Clinical attachment level, CEJ: Cementoenamel junction; FGG: Free gingival graft; GR: Gingival recession; KT: Keratinized tissues; MGJ: Mucogingival junction; MRG: Mean root coverage; PD: Pocket depth; PRF: Platelet-rich fibrin; PST: Pinhole surgical technique; RC: Root coverage; SCTG: Subepithelial connective tissue graft

\section{Introduction}

A periodontal plastic surgery is a surgical procedure that is performed to correct or eliminate anatomic, developmental, or traumatic deformities of gingival or alveolar mucosa [1]. Gingival recession (GR) is known as the migration of the gingival margin apically to the cementoenamel junction (CEJ), which in turn exposes the root surface and reduces the vestibular depth. Generally, GR is not an acute condition, it occurs gradually over the years which makes it sometimes unnoticed until it starts to cause symptoms. GR is common to occur in adults over the age of 40 , but it may also occur in teenagers, or around the age of ten years [2]. It is caused by periodontal diseases, improper dental flossing, aggressive tooth brushing, incorrect occlusal relationships, mechanical compressions, faulty orthodontic treatments, and prominent roots in thin plate of bone. GR appears as localized or generalized defects [3]. Various classifications have been proposed to classify the gingival recession, but the most widely followed one is the Miller's classification system [4] which describes the gingival recession defects according to the extension of recession to the mucogingival junction (MCJ), interdental bone loss and proximal bone loss as following;

i. Class I: Recession within attached gingiva, no loss of interdental bone and interdental papillae at its full height.

ii. Class II: Recession extending to or beyond the mucogingival junction (MGJ), no loss of the interdental bone and the interdental papillae at its full height.

iii. Class III: Recession extending to or beyond the MGJ, there is a loss in the interdental bone and a partial reduction in the height of interdental papillae. 
iv. Class IV: Recession extending to or beyond the MGJ, loss of interdental bone apically to the recession defect. and a complete loss of the interdental papillae.

Consequences of GR include the unaesthetic look of the teeth, hypersensitivity, and the development of root caries due to the exposure of root and accumulation of plaque. Hereby, the main purposes of root coverage (RC) procedures are good esthetics, reduction of hypersensitivity, treatment of the inconsistency of the gingival margin and augmentation of keratinized tissues [5]. Numerous techniques have been established to treat the GR either single or multiple defects including restorative, orthodontic, and surgical options. However, the most common modalities for surgical root coverage involve free gingival autograft [6], subepithelial connective tissue graft [7], lateral repositioned flap [8], double papilla flap [9], coronally repositioned flap and guided tissue regeneration techniques [10]. Although the most critical factor of gingival recession treatment is the predictability as it is measured by the frequency of complete root coverage, the success rates of $\mathrm{RC}$ procedures vary because $\mathrm{RC}$ depends on several factors, including location and classification of the gingival recession and the technique used. An increase in gingival height regardless of the number of millimeters is considered as a successful outcome of gingival augmentation procedures [11].

Despite the considerable number of studies that have been done for RC, surgical difficulties, time, and patients' discomfort are still the main obstacles. However, the morbidity associated with the secondary graft sites has generated the interest and need of other modalities to achieve the esthetic and functional requirements without any complications, reaching the patient comfort and satisfaction. In our study, we highlight the achievability of a novel surgical technique that is called pinhole surgical technique (PST) as it is a minimally invasive treatment that reverses GR without using donor graft, flap elevation ,or sutures [12].

\section{Technique of PST}

A novel approach treatment using a Pinhole surgical technique (PST) was introduced by John Chao [12] to reverse multiple GR defects. Unlike surgical grafting techniques, PST is minimally invasive with neither incision nor suture. In PST, a needle is used to pierce the mucosa and make a small hole in the gingival tissue 4-5 $\mathrm{mm}$ beyond the MGJ (in alveolar mucosa) apical to the gingival defect, where specially designed instruments are used to gently loosen the gingival tissues expanding the tissues in an apicocoronal direction as all the muscular and fibrous adhesions are released and the periosteum is elevated from underlying bone creating full-thickness flap. In the case of mandibular premolars involvement, the hole is made at the midfacial of adjacent cuspid. For multiple teeth involvements, holes are spaced approximately 2-4 teeth apart; the exact location depends on some factors such as the recession severity, frenum, vascularity of the area, depth of the vestibule, and tissue type [12]. The elevation of the flap is guided by the visualization of the instrument movements through the gingival mucosa. When the desired flap becomes freely mobile without any tension, the flap will be able to advance coronally to glide it over the receded part of the tooth and cover the exposed roots 3-4 mm coronal to $\mathrm{CEJ}$ [12].

For stabilization of the flap, resorbable collagen strips are placed through the pinhole and pushed into the interdental papillae to assist and hold the new gingival position which in turn results in fast healing process. The number of membranes depends on the quantity required to generate sufficient tissues at the overcorrected gingival position [12]. Gentle digital pressure is applied to the flap for 5 minutes and the entry incision is left to heal by first intension without sutures or periodontal dressing or tissue adhesives. As to say simply, adjusting the existing gingival tissues to the coronal position without secondary surgical site or releasing incision or sutures. Therefore, patients can expect minimal post-operative complications such as pain, swelling, and bleeding $[12,13]$. Postoperative instructions include minimizing disturbance of the wound by any physical object, $0.12 \%$ chlorhexidine mouth rinse, and avoidance of brushing for 6 weeks. After 6 weeks, the patient should be instructed to use an extra soft brush in vertical strokes moving in a vestibular-coronal direction only. Flossing instructions emphasize just breaking the contact point away from the apical line angle of the teeth and not touching the gingiva $[14,15]$.

\section{Aim}

The purpose of this review was to highlight the achievability of the pinhole technique in the treatment of gingival recessions as it is one of the recent modalities of root coverage with minimal complications.

\section{Material and Method}

\section{Eligibility criteria}

Studies eligible for inclusion in this review were English published articles, human studies with clinically diagnosed gingival recession defects [4] ( Miller's Class I , Class II, or Class III ), availability of preoperative and postoperative measurements and surgical treatment of gingival recession by pinhole technique with follow up 6 months at least. Articles of animal studies, in vitro, and other techniques of root coverage cases were not evaluated such as laterally displaced flap, obtain free gingival graft, or subepithelial connective tissue graft. Also, letters, editorials, reviews and unpublished data were excluded.

\section{Search strategy and study selection}

The study protocol used for this review was based on the review of the previous publications which were published from 2010 to July 2020. We used databases from scientific websites such as PubMed, Scopus, and Google scholar to find studies reporting on the pinhole technique. The research process involved specific keywords in the main query "pinhole surgical technique" - "hole technique"- "gingival recession treatment"- "root 
coverage" to find more articles related to our subject. All eligible studies were considered in this article, the titles and abstracts of potential references were manually seen to exclude unrelated publications and the full texts of the relevant papers were then reviewed. Authors, years of publication, type of study, number of patients, number of roots covered, treatment type, outcomes were extracted from the selected studies.

\section{Statistical Analysis}

Our initial aim was to conduct meta-analysis but due to marked heterogeneity and inconsistency of data among the included studies, no statistical analysis was performed.

\section{Outcomes Measures}

Types of outcome parameters included the changes in gingival tissues expressed as the mean root coverage (MRG), thickness of keratinized tissues (KT) gained at the end of follow up period, patients' postoperative complications (swelling, pain ,and discomfort during the healing period) and patients' satisfaction and preference in term of aesthetic results.

\section{Results}

Some articles were directly eliminated after reading the titles. At this stage there were 324 articles where 96 articles included and 228 were excluded because they were not relevant to the subject and didn't met the included criteria of the study. Then, the inclusion and exclusion criteria were defined to give a total of eight articles for full-text reading. After reading these articles, three more articles were excluded, as they did not fulfill the inclusion criteria. Original studying articles and case reports were investigated by the authors. The results of this literature review were presented in Figure 1 where only five studies [12,14-16] were considered appropriate.

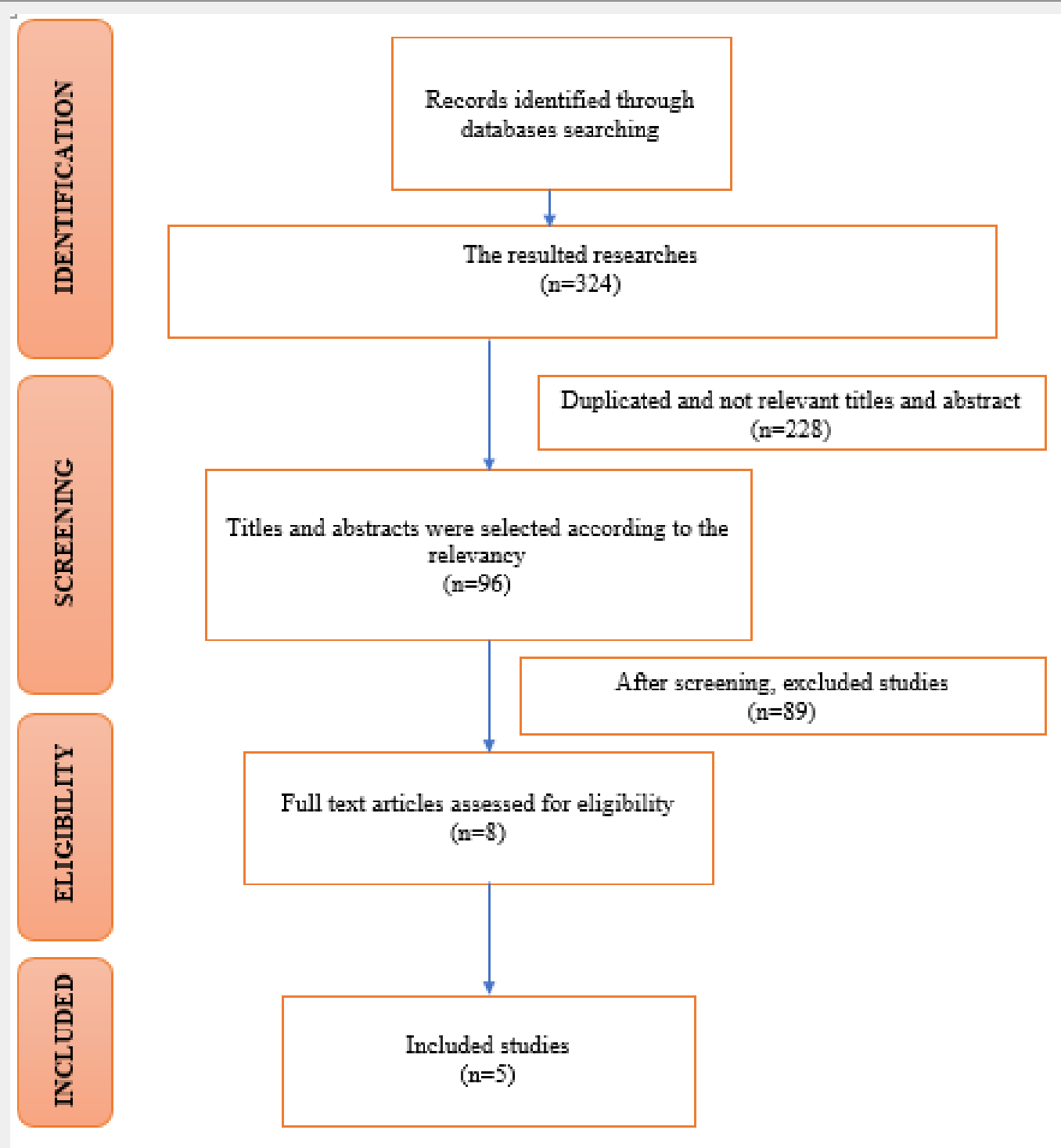

Figure 1: Article selection flow chart of screening process. 


\section{Characteristics of the included articles}

The data extracted from the articles are tabulated in Tables 1 \& 2. In the five studies, the total number of patients ranges from 2-43 patients with 10-121 gingival recession defects. For all the studies, all patients who entered each study were properly accounted for at completion with follow-up periods ranged from 6 to 93 months. Data regarding percentage and mean of root coverage, gain in keratinized gingiva, esthetic results, postoperative complications, and patient satisfaction were reported in Table 2. In 2012, Chao [12] made a retrospective study using PST on 43 patients with 121 gingival recession defects, Miller's class I and II were in 85 sites while Miller's class III was presented in 36 sites. The author used a threaded acellular dermal matrix (ADM) to secure the flap with his PST in the mean duration of all sites $22.3 \pm 10$. The author reported that a complete healing for all the cases was established after 6 weeks without any observed difference in color before and after PST. Also, he concluded that the percentage and mean root coverage (MRC) were $88.4 \%$ and $3 \pm 1.1$ respectively. In addition, the post-operative parameters for the 121 sites were positive where pocket depth (PD) reduced $1.4 \mathrm{~mm}$, clinical attachment level (CAL) gained $4.4 \mathrm{~mm}$ and KT gained $1.3 \mathrm{~mm}$. The total predictability and effectiveness of the total patients were $69.4 \%$ and $88.4 \% \pm 19.8 \%$, respectively. Also, patient-based outcomes such as the esthetic satisfaction was $94.9 \% \pm 1 \%$, the mean overall patient satisfaction over the study was $95.1 \% \pm 1.2 \%$, dental sensitivity was informed by 12 (48\%) patients after the PST and no postoperative complications were detected including pain, swelling, and bleeding.

Table 1: The use of Pinhole surgical Technique (PST) in treatment of gingival recession.

\begin{tabular}{|c|c|c|c|c|c|c|}
\hline $\begin{array}{l}\text { Author } \\
\text { /year }\end{array}$ & Type of study & $\begin{array}{l}\text { Patients' } \\
\text { number }\end{array}$ & $\begin{array}{l}\text { Number / classes of } \\
\text { gingival defects }\end{array}$ & $\begin{array}{l}\text { Maximum fol- } \\
\text { low up period }\end{array}$ & $\begin{array}{l}\text { Treatment tech- } \\
\text { niques }\end{array}$ & Outcomes \\
\hline Chao [12] & $\begin{array}{l}\text { Retrospective } \\
\text { study (case } \\
\text { series) }\end{array}$ & 43 patients & $\begin{array}{c}121 \text { sites } \\
\text { (Class I, class II \&III) }\end{array}$ & 18 months & $\begin{array}{l}\text { PST using a biore- } \\
\text { sorbable membrane } \\
\text { (acellular dermal ma- } \\
\text { trix) as graft material. }\end{array}$ & $\begin{array}{l}\text { The results indicated that } \\
\text { PST holds promise as a mini- } \\
\text { mally invasive, predictable, } \\
\text { effective, and time- and } \\
\text { cost-effective method. }\end{array}$ \\
\hline Reddy [16] & Case series & 5 patients & $\begin{array}{l}18 \text { sites } \\
\text { (Class I, II) }\end{array}$ & 6 months & $\begin{array}{l}\text { PST using cut collagen } \\
\text { membranes }(2 \mathrm{~mm}) \text { at } \\
\text { interdental papillae } \\
\text { until the sufficient } \\
\text { fullness. }\end{array}$ & $\begin{array}{l}\text { PST could be a } \\
\text { predictive treatment meth- } \\
\text { odology for the management } \\
\text { of multiple GR defects with } \\
\text { less invasive procedure, } \\
\text { minimal patient discomfort } \\
\text { and maximal esthetic } \\
\text { outcomes. }\end{array}$ \\
\hline Anuroopa [15] & Case report & 2 patients & 10 sites (Class I \& II) & 6 months & $\begin{array}{l}\text { PST using PRF to } \\
\text { support and hold the } \\
\text { gingiva in its new } \\
\text { position. }\end{array}$ & $\begin{array}{l}\text { PST is a promising tech- } \\
\text { nique to treat Miller's Class } \\
\text { I - II recession. In addition, } \\
\text { the adjunctive use of PRF } \\
\text { plays vital role in early } \\
\text { wound-healing, develop- } \\
\text { ment, and maturation of a } \\
\text { normal vasculature. }\end{array}$ \\
\hline & & & & & & \\
\hline
\end{tabular}




\begin{tabular}{|c|c|c|c|c|c|c|}
\hline Chao [14] & Case report & 2 patients & $\begin{array}{l}27 \text { sites } \\
\text { (Class I, II) }\end{array}$ & $46-93$ months & $\begin{array}{l}\text { PST using a biore- } \\
\text { sorbable membrane } \\
\text { or acellular dermal } \\
\text { matrix as graft } \\
\text { material to hold the } \\
\text { mucogingival tissues. }\end{array}$ & $\begin{array}{l}\text { PST can be utilized to satisfy } \\
\text { the parameters for correct- } \\
\text { ing multiple recession sites } \\
\text { in a } \\
\text { fast and easy way giving } \\
\text { long term results. }\end{array}$ \\
\hline $\begin{array}{c}\text { Agarwal et al. } \\
\text { [17] }\end{array}$ & Case series & 10 patients & 20 sites (Class I, II) & $\begin{array}{l}\text { 6-month fol- } \\
\text { low-up }\end{array}$ & $\begin{array}{l}\text { PST was used along } \\
\text { with the placement } \\
\text { of titanium-prepared } \\
\text { platelet-rich fibrin } \\
\text { (T-PRF) membrane. }\end{array}$ & $\begin{array}{l}\text { PST gives instant esthetic } \\
\text { results with minimally inva- } \\
\text { sive surgical procedures. }\end{array}$ \\
\hline
\end{tabular}

Table 2: The PST outcome parameters regarding percentage and mean root coverage, gain of keratinized tissues, esthetic results, postoperative complications and patient satisfaction.

\begin{tabular}{|c|c|c|c|c|c|}
\hline $\begin{array}{c}\text { Authors / } \\
\text { year }\end{array}$ & $\begin{array}{l}\text { Percentage and mean root } \\
\text { coverage (MRC) }\end{array}$ & $\begin{array}{l}\text { Keratinized tissues } \\
\text { (KT) gain }\end{array}$ & Esthetic results & $\begin{array}{l}\text { Postoperative complica- } \\
\text { tions }\end{array}$ & $\begin{array}{l}\text { Patient satisfac- } \\
\text { tion }\end{array}$ \\
\hline Chao [12] & $\begin{array}{l}\text { The percentage and mean } \\
\text { MRC were } 88.4 \% \text { and } 3 \pm 1.1 \text {, } \\
\text { respectively. }\end{array}$ & $\begin{array}{c}\text { Main KT gain was } \\
1.3 \mathrm{~mm} .\end{array}$ & $\begin{array}{c}\text { The esthetic satisfac- } \\
\text { tion was } 95.1 \% \text { and } \\
\text { was realized within } \\
\text { a mean } 7.34 \pm 13.5 \\
\text { days. }\end{array}$ & $\begin{array}{l}\text { The dental sensitivity was in- } \\
\text { formed by } 12(48 \%) \text { patients } \\
\text { after the PST and no other } \\
\text { postoperative complications } \\
\text { were detected including pain, } \\
\text { swelling and bleeding. }\end{array}$ & $\begin{array}{c}\text { The mean overall } \\
\text { patient satisfaction } \\
\text { over the study was } \\
95.1 \% \pm 1.2 \%\end{array}$ \\
\hline Reddy [16] & $\begin{array}{c}\text { The overall MRC was found } \\
\text { to be } 96.7 \% \\
\text { in } 18 \text { sites with only two } \\
\text { sites which achieved partial } \\
\text { root } \\
\text { coverage. }\end{array}$ & $\begin{array}{l}\text { There was statistically } \\
\text { significant increase in } \\
\text { the KT }(\mathrm{P} \leq 0.0001) \\
\text { where the mean } \\
\text { Width of KT } \\
\text { preoperatively as } 2.11 \\
\text { mm and postoperative } \\
\text { as } 2.78 \mathrm{~mm} \text {. }\end{array}$ & $\begin{array}{l}\text { Perfect esthetic } \\
\text { results and color } \\
\text { match. }\end{array}$ & $\begin{array}{l}\text { Edema was the only compli- } \\
\text { cation which was sever on the } \\
\text { second day and reduced later. }\end{array}$ & Not reported. \\
\hline $\begin{array}{c}\text { Anuroopa } \\
{[15]}\end{array}$ & $\begin{array}{l}\text { The MRC achieved in the } \\
\text { cases averaged between } \\
\text { 93-95\% with a complete } \\
\text { coverage only in } 3 \text { teeth out } \\
\text { of the } 10 \text { teeth treated. }\end{array}$ & $\begin{array}{l}\text { There was a gain in KT } \\
\text { in the recessed area } \\
\text { with a mean of } 1.2 \mathrm{~mm}\end{array}$ & $\begin{array}{l}\text { Patient satisfaction } \\
\text { was good on the es- } \\
\text { thetic point of view } \\
\text { with no difference in } \\
\text { the color change. }\end{array}$ & $\begin{array}{l}\text { No postoperative complica- } \\
\text { tions. }\end{array}$ & Not reported. \\
\hline Chao [14] & $\begin{array}{l}\text { Not reported } \\
\text { Only mentioned that mu- } \\
\text { cogingival apparatus was } \\
\text { fully restored to CEJ. }\end{array}$ & KT were regenerated. & $\begin{array}{l}\text { Aesthetic balance } \\
\text { was recreated with a } \\
\text { perfect tissue match. }\end{array}$ & Not reported & $\begin{array}{l}\text { highly satisfactory } \\
\text { outcomes. }\end{array}$ \\
\hline $\begin{array}{c}\text { Agarwal et al. } \\
\text { [17] }\end{array}$ & $\begin{array}{l}\text { The MRC obtained was } 87 \% \\
\text { at 6-month follow-up. }\end{array}$ & $\begin{array}{l}\text { KT significantly in- } \\
\text { creased from baseline } \\
\text { to } 6 \text { months. }\end{array}$ & $\begin{array}{l}\text { The esthetic ac- } \\
\text { ceptance in terms } \\
\text { of color match and } \\
\text { tissue blending was } \\
\text { reported as good. }\end{array}$ & $\begin{array}{l}\text { Postoperative bleeding, } \\
\text { swelling, and pain were } \\
\text { reported as mild and for short } \\
\text { duration. }\end{array}$ & $\begin{array}{l}\text { The patient satis- } \\
\text { faction was found } \\
\text { to be high with VAS } \\
\text { value: } 3.4 \pm 0.84 \text {. }\end{array}$ \\
\hline
\end{tabular}

The same author in 2019 displayed long term results of 4693 months of PST on 2 cases with 27 sites of gingival defects and concluded that the mucogingival apparatus was fully restored with prefect tissue color match, regenerated keratinized tissues, no bleeding on probing and normal probing depth. Also, he reported that the patient outcome was highly satisfactory [14]. In 2017, Reddy [16] established a case series study on 5 patients with 18 gingival recession sites ranged 2-4mm Miller's class I and
II in follow up periods 1, 7 days, 3 months, and 6 months. After 6 months, the overall MRC was found to be $96.7 \%$ in 18 sites with only two sites which achieved partial root coverage and there were a statistically significant increases in the KT. Only, edema was the reported postoperative complication in the cases. Anuroopa et al. [15] used PST with platelet-rich fibrin (PRF) instead of collagen strips on 2 patients with 10 gingival recession defects, and stated that the MRC achieved 93-95\% with a complete coverage only in 
3 teeth out of the 10 teeth treated, KT gained with mean $1.2 \mathrm{~mm}$ and there was a significant patient satisfaction without any postoperative complications. Yet, all the included clinical studies provided at the beginning of the treatment, adequate oral hygiene care including comprehensive instructions, all the authors mentioned the classes of recession they treated which was I, I Miller's classification except Chao[12] treated class I, II and III recession, no study was reported including the class IV recession. Although, all of the included studies used the same procedure of the PST with neither sutures nor incisions, Chao [12,14] and Reddy [16] used bioresorbable acellular dermal matrix as graft material to support the gingival in its coronal position while Anuroopa et al. and Agarwal et al [17] used platelet-rich fibrin (PRF) membrane in their technique to hold and support the mucogingival tissue complex.

\section{Discussion}

Arrays of techniques are advocated for root coverage, considering the conventional autogenous grafting to be the gold standard [15]. However, additional postoperative pain, esthetics, and second harvest surgical site are the challenges of surgical autogenous grafting such as free gingival graft (FGG) and subepithelial connective tissue graft (SCTG). Although, both techniques have donor sites but the FGG had a higher incidence of postoperative pain in the early wound healing period than SCTG [18] because of the primary intention healing of the donor site. Also, the esthetic results are much better in SCTG than FGG but still, the esthetic appearance of the treated recipient site in SCTG is somehow different from that of the neighboring tissues due to the chromatic difference between the uncovered epithelialized part of the graft and the adjacent soft tissues, or maybe partial exposure and dehiscence of the connective tissue graft or maybe the difference in tissue thickness between the grafted site and the adjacent tissues [19]. In contrast to PST, the pain is minimal, perfect esthetic results and donor surgical site is absent $[14,20]$. These increase the patient's acceptance for PST and make it easier for the periodontist to manipulate the surgical procedure with less time-consuming. In addition, autogenous grafting is limited in treating one or two gingival recession defects because it depends on the ability to harvest an adequate amount of tissue to cover the desired area while PST can treat an unlimited number of gingival recession defects at one time.

According to Griffin et al. [21], the most noteworthy indicator for postoperative pain was the time length of the surgery especially when using autogenous graft but the included studies reported that PST was done in a short duration of the procedure even if there were multiple recession defects. Also, when analyzing the significant increase in parameters in PST, recession reduction and KT increase was found to be similar to the previous studies with modified CAF $[15,22]$. Besides, PST does not involve sutures and suturing techniques, which reduces the time and cost for performing the suturing procedure. Furthermore, the authors
[12,14-17] used either resorbable collagen strips or PRF to regenerate and support the periodontal tissues in its new position as they were used in many studies [23-26] with confirmed clinical results of periodontal tissues regeneration. In addition, PRF was proved to release collagen 1 and sustained release and protection against proteolytic degradation of endogenous fibrogenic factors that are important for wound healing [27], however, more histological evidences are needed. Another superiority of this technique is that there is no need for vertical incisions with envelope incisions and semilunar incisions [28], this makes it less traumatic procedure which in turn fastens the healing. However, the mucoperiosteal reflection is known to affect the blood supply to the tissues temporarily which is not well accepted [29]. In PST, there is no actual separation of the underlying tissues, the integrity of the tissue is still maintained with its periosteum without any changes in vascularity. So, there is no disruption of the vascular supply, this explains the faster rate of healing without any complication and no scar formation which resulting in additional biological and esthetic advantages [16]. Also, the patient can observe the root coverage immediately after the procedure [1517] which increases the overall satisfaction level of the patients.

However, the benefits of using PST could be summarized as multiple root coverage with unlimited number of teeth, regeneration of mucogingival apparatus without scalpel, incision, sutures, and donor site which in turn decrease the risk of the second surgical site and graft exposure, give perfect esthetic long term results, reduce the surgical duration, enhance faster healing without no scar, minimize postoperative complications and provide immediate observed results. While the limitations of the PST involve the requirement of special instruments for the flap elevation and the need of particular technical skills to avoid flap perforation. Besides, it is risky in treatment of lingual gingival defects and cannot be used in treatment of palatal recession defects. The success of reversing the gingival recession depends on the presence of bone and interdental papilla height between the teeth [16]. Therefore, the results in cases of severe bone loss or tissue support will be less predictable. Also, patients with traumatic activities such as aggressive brushing and bruxism will act as risk factors for PST success. Furthermore, Heavy smoking, uncontrolled or poorly controlled diabetes, and medications that can compromise the healing process could increase the risk of postoperative complications [20].

\section{Limitation of the study}

Due to the small number of publications and the heterogeneity of procedures such as different in recession classes, follow-up periods, and type of grafting, the study characteristics were considered too variable. In addition, the predictability of PST should include the root length factor, also no studies have been done in the treatment of class IV Millar's recessions. Furthermore, until now there is no histological studies available to support the clinical evidence. 


\section{Advances in Dentistry \& Oral Health}

\section{Conclusion}

Minimally invasive periodontal procedure is a required demand in the periodontal clinics where there is less extensive surgical manipulations to restore the lost tissues [30], so, using the conservative surgical technique with less postoperative complications to regenerate the periodontium and cover roots is the needed approach. In conclusion, the main outcome of comparing the included clinical studies was that the PST achieves non-invasive treatment of the unlimited number of GR defects with high predictable esthetic results in one appointment without donor sites or exposure of the graft, which make PST a promising modality that reaches the periodontist ambition. Due to the confined number of relevant published data of PST, limited sample size, and short follow up periods, we could not give definite evidence for the advantages of PST. More clinical and histological studies including randomized clinical trials, larger numbers of patients, and long follow-up periods are required to evaluate the feasibility of PST in the treatment of GR.

\section{References}

1. Takei H, Azzi R, Han T (2009) Periodontal plastic and esthetic surgery. In: Carranza FA, editor. Clinical Periodontology. $10^{\text {th }}$ ed. St. Louis: Elsevier pp. 1005-1130.

2. Nazir MA (2017) Prevalence of periodontal disease, its association with systemic diseases and prevention. Inter J Health Sci 11(12): 72-80.

3. Koppolu P (2012) Gingival Recession: Review and Strategies in Treatment of Recession. Case Rep Dent 2012: 563421.

4. Pini Prato G (2011) The Miller classification of gingival recession: limits and drawbacks. J Clin Periodontol 38(3): 243-245.

5. Needleman I, Sanz M (2002) Periodontal plastic surgery for treatment of localized gingival recessions: a systematic review. J Clin Periodonto 29(3): 178-94.

6. Brackett, Robert C, Anthony W, Gargiulo (1970) Free gingival grafts in humans. J Periodontol 41(10): 581-586.

7. Burton L, Langer L (1985) Subepithelial connective tissue graft technique for root coverage. J Periodontol 56(12): 715-720.

8. Grupe, Harold E, Richard F, Warren (1956) Repair of gingival defects by a sliding flap operation. J Perio 27(2): 92-95.

9. Cohen D, Walter, Stanley E, Ross (1986) The double papillae repositioned flap in periodontal therapy. J Periodontol 39(2): 65-70.

10. Harris, Randall J (1997) A comparative study of root coverage obtained with guided tissue regeneration utilizing a bioabsorbable membrane versus the connective tissue with partial-thickness double pedicle graft. J Periodontol 68(8): 779-790.

11. Wennström JL, Zucchelli G (1996) Increased gingival dimensions. A significant factor for successful outcome of root coverage procedures? A 2-year prospective clinical study. J Clin Periodontol 23(8): 770-777.

12. Chao J (2012) A novel approach to root coverage: Pinhole surgical technique. Int J Periodontics Restorative Dent 32(5): 521-531.

13. Bernimoulin JP Lüscher B, Mühlemann HR (1975) Coronally repositioned periodontal flap. Clinical evaluation after one year. J Clin Perio 2(1): 1-13.
14. Chao J (2019) Our roots aren't showing, using the Pinhole Surgical Technique to treat multiple gingival defects without scalpels or sutures. Dentaltown magazine 74820: 100-104.

15. Anuroopa P, Ambadi S Naidu P, Savita S (2018) Treatment of Gingival Recession by a Novel Pinhole Technique- A Report of Page 3 of 5 Two Cases. J Dent Oral Disord Ther 6(2): 1-5.

16. Reddy SSP (2017) Pinhole Surgical Technique for treatment of marginal tissue recession: A case series. J Indian Soc Periodontol 21(6): 507-511.

17. Agarwal MC, Kumar G, Manjunath RG, Karthikeyan SS, Gummaluri SS (2020) Pinhole surgical technique - A novel minimally invasive approach for treatment of multiple gingival recession defects: A case series. Contemp Clin Dent 11(1): 97-100.

18. Wessel JR, Tatakis DN (2018) Patient outcomes following subepithelial connective tissue graft and free gingival graft procedures. J Periodontol 79(3): 425-30.

19. Silva AC, Moura CC, Ferreira JA, Magalhaes Dd, Dechichi P, et al. (2016) Biological Effects of a Root Conditioning Treatment on Periodontally Affected Teeth-An In Vitro Analysis. Braz Dent J 27(2): 160-168.

20. Chambrone L, Tatakis D (2016) Long Term Outcomes of Untreated Buccal Gingival Recessions: A Systematic Review and Meta-Analysis. J Periodontol 87(7): 796-808.

21. Griffin TJ, Cheung WS, Zavras AI, Damoulis PD (2006) Postoperative complications following gingival augmentation procedures. J Periodontol 77(12): 2070-2079.

22. Zucchelli G, De Sanctis M (2000) Treatment of multiple recession-type defects in patients with esthetic demands. J Periodontol 71: 15061514.

23. Berlucchi I, Francetti L, Del Fabbro M, Basso M, Weinstein RL (2005) The Influence of Anatomical Features on the Outcome of Gingival Recessions Treated with Coronally Advanced Flap and Enamel Matrix Derivative: A One-Year Prospective Study. J Periodontol 76(6): 899-907.

24. Vincenzi G, De Chiesa A, Trisi P (1998) Guided Tissue Regeneration Using a Resorbable Membrane in Gingival Recession-Type Defects: A Histological CAs Report in Humans. Int J Periodontics Restorative Dent 18(1): 24-33.

25. McGuire MK, Cochran DL (2003) Evaluation of Human Recession Defects Treated with Coronally Advanced Flap and Either Enamel Matrix Derivative or Connective Tissue. J Periodontol 74(8): 11261135.

26. Shantipriya Reddy, Prasad MGS, Nirjhar Bhowmik, Savita Singh, Huzaifa Rashid Pandit, et al. (2016) Vestibular incision subperiosteal tunnel access (VISTA) with platelet rich fibrin (PRF) and connective tissue graft (CTG) in the management of multiple gingival recession- A case series. Int J App Dent Sci 2: 34-37.

27. Miron RJ, Kobayashi MF, Bishara M, Zhang Y, Hernandez M, et al. (2016) Platelet-rich fibrin and soft tissue wound healing: A systematic review. Tissue Eng Part B Rev 23(1): 83-99.

28. Tarnow DP (1986) Semilunar coronally repositioned flap. J Clin Periodontol 13(3): 182-185.

29. Misch C (2008) Contemporary Implant Dentistry. $1^{\text {st }}$ ed. St. Louis: Mosby Elsevier p. 78.

30. Rathod DB, Vishnoi S, Chandran S(2016) Minimum invasive technique for regeneration therapy. Int J Curries Res 8:343 
This work is licensed under Creative Commons Attribution 4.0 License DOI: 10.19080/ADOH.2020.13.555855
Your next submission with Juniper Publishers will reach you the below assets

- Quality Editorial service

- Swift Peer Review

- Reprints availability

- E-prints Service

- Manuscript Podcast for convenient understanding

- Global attainment for your research

- Manuscript accessibility in different formats

( Pdf, E-pub, Full Text, Audio)

- Unceasing customer service

Track the below URL for one-step submission https://juniperpublishers.com/online-submission.php 